\title{
THE TECHNICALIZATION AND PRACTICE OF LABOR CARE: A PHENOMENOLOGICAL APPROACH BASED ON HUSSERL ${ }^{1}$
}

\author{
Valdecyr Herdy Alves², Pedro Manuel Santos Alves³, Stela Maris de Mello Padoin ${ }^{4}$
}

\footnotetext{
${ }^{1}$ Results of reflections in a post-doctoral fellowship, presented to the Post-Doctoral Nursing Program, Programa de Pós-Graduação em Enfermagem, Universidade Federal de Santa Maria (UFSM) in 2014.

${ }^{2}$ Ph.D. in Nursing. Professor, Departamento Materno-Infantil e Psiquiatria, Escola de Enfermagem Aurora de Afonso Costa, Universidade Federal Fluminense. Niterói, Rio de Janeiro, Brazil. E-mail: herdyalves@yahoo.com.br

${ }^{3}$ Ph.D. in Philosophy. Professor, Departamento de Filosofia, Universidade de Lisboa. Lisboa, Portugal. E-mail: psalves2@gmail.com

${ }^{4}$ Ph.D. in Nursing. Professor, Departamento de Enfermagem, UFSM. Santa Maria, Rio Grande do Sul, Brazil. E-mail: stelamaris_padoin@ hotmail.com
}

\begin{abstract}
Childbirth is one of the most important experiences in the world of life, which women and their families have experienced for a long time without the intervention of techniques and without the presence of people who were not part of their world. The technical and scientific reasons inherent in the field of labor and birth began to occupy the space of the objectification of the world's facts and rationality started to prevail. Moving back to the origins of the technicalization of childbirth care, this article intends to discuss the reduction of labor to a clinical process focused on its purely biological dimension. Its inspiring base is Husserl's phenomenological philosophy, the mathematization of nature and technicalization of our relationship with the world, in order to expand perspectives beyond the health techniques, understand intersubjectivity and rescue human dignity.
\end{abstract}

DESCRIPTORS: Women's health. Obstetric nursing. Humanization of assistance. Nursing care. Obstetrics.

\section{A TECNICIZAÇÃO E A PRÁTICA DO CUIDADO AO PARTO: UMA ABORDAGEM FENOMENOLÓGICA A PARTIR DE HUSSERL}

RESUMO: O parto constitui-se como uma das mais importantes experiências no mundo da vida, vivenciado, por muito tempo, pelas mulheres e suas famílias sem a intervenção de técnicas e a presença de pessoas que não faziam parte do seu mundo. As razões técnica e científica inerentes ao campo do parto e nascimento passaram a ocupar o espaço da objetivação dos fatos do mundo e a racionalidade passou a predominar. Recuando até as origens da tecnicização da prática do cuidado ao parto, este texto pretende refletir acerca do parto como um processo clínico centrado sobre sua pura dimensão biológica. Tem como base inspiradora a filosofia fenomenológica, de Husserl, a matematização da natureza e a tecnicização de nossa relação com o mundo. Para ampliar o olhar para além das técnicas em saúde, compreender a intersubjetividade e resgatar a dignidade humana.

DESCRITORES: Saúde da mulher. Enfermagem obstétrica. Humanização da assistência. Cuidados de enfermagem. Obstetrícia.

\section{LA TECNIFICACIÓN Y LA PRÁCTICA DEL CUIDADO AL PARTO: UNA ABORDAJE FENOMENOLÓGICA DESDE HUSSERL}

RESUMEN: El parto se constituye como una de las experiencias más importantes en el mundo de la vida, vivido por mucho tiempo, por las mujeres y sus familias sin la intervención de técnicas y de la presencia de personas que no hacían parte de su mundo. Las razones técnicas y científicas inherentes al ámbito del parto y nacimiento comenzaron a ocupar el espacio de la objetivación de los hechos del mundo y la racionalidad empezó a prevalecer. Retrocediendo a los orígenes de la tecnificación de la práctica del cuidado al parto, este artículo se propone a reflexionar sobre la reducción del parto a un proceso clínico centrado en la pura dimensión biológica. Tiene como base la filosofía fenomenológica de Husserl, la matematización de la naturaleza y la tecnificación de nuestra relación con el mundo. Esto con el objetivo de ampliar las perspectivas más allá de las técnicas en salud, comprender la intersubjetividad y rescatar la dignidad humana. DESCRIPTORES: Salud de la mujer. Enfermería obstétrica. Humanización de la atención. Atención de enfermería. Obstetricia. 


\section{INTRODUCTION}

What is characteristic about Phenomenology: instead of departing from the premise of an objective world, as a reality that exists beforehand, before all subjective operations, it departs from the subjectivity, from its experiences and processes that constitute meaning, and obtains the world as a result or correlate of its experience. Hence, for Phenomenology, there is not one world, except as a correlate of a system of experiences, which always take place in the first person (in the form: $I$ ). At the same time, they are always validated intersubjectively and confirmed in community and communicative life processes. ${ }^{1}$

Hence, from the start, the subjectivity that experiences the world is always immersed in intersubjective processes of life and communication, so that the world that emerges as a correlate of the experience is always, and from its origin, a common world. In that context, more fundamental than knowing what is the world we are confronted with as a correlate of our experience is to know how the world that is there appears to us, available to our knowledge, our action and our technical-scientific manipulation. That is the theoretical place of Phenomenology: its interest ranges from the world we have experienced to the sense and meaning of our experience in the world. ${ }^{1}$

This phenomenological question is therefore regressive: it moves from the world to the subjectivity that grants meaning. Thus, phenomenology $y^{1-2}$ starts by characterizing the appearance of a world as a web of experiences that give meaning, which are intersubjective and communicative from the start. Two cores are immediately evidenced for this regressive inquiry. The first question could be formulated as follows: is their something like a primitive form that originates the experience of the world and what would be its meaning? The second question would be as follows: as subjectivity always gives rise to a communicative intersubjectivity, unified in different forms of community, would the meaning of the world experience be the same everywhere or would it translate a rooting of the subjects in the different forms of their community life?

Phenomenology answers the first question as follows: there truly exists a primitive, founding form of the world experience, which underlies all others and which all others derive from. It is designated by the concept of lifeworld (Lebenswelt) and the project of its phenomenological description takes the form of an ontology of the life world. What the second question is concerned, Phenomenology can answer it as follows: the lifeworld, as a primitive form of the world experience, has been a cultural world from the very beginning, and therefore a world whose meaning always takes on different forms in the horizon of each human community and each historical time. Thus, the world experience, in its most original form, is crossed by an intrinsic multiplicity and historicity. ${ }^{1-2}$

The structures of meaning of the lifeworld, as a primary form of our world experience, can be grouped in the following elements: ${ }^{1-2}$

1. A perceptive capturing of things, in an open world, on a space and time based on the "here" and "now" of experience;

2. An intersubjective capturing of other subjects, in a no longer perceptive experience, related to simple bodies, but empathetic, related to the capturing of other " $\mathrm{I}$ ' $\mathrm{s}$ " in the unit of a shared "we";

3. An insertion in the horizon of a common community of life, with its own historicity and understanding of the culturally constructed world, as opposed to other communities, perceived with the meaning of "other", "extraneous" or even "strange";

4. A tissue of valuations, through which the world of things and subjects, in its communitarian relations, is always experienced through values that give meaning to the "good", the "well", the "fair" and its opposites;

5. A practical, active insertion in the world, based on personal and collective life projects.

Thus, it is considered that this structure, being the basic form a world experience rests on, permits different forms to put it in practice.

In that sense, we can discuss the lifeworld of the ancient Greeks or Chinese, of the inhabitants of Papua or any other historical life communities. Inside a large life community, such as a country or nation, particular forms of a common life unit exist, with their distinctive signs and different form of giving meaning. All of them contain not only a peculiar representation, but also a valuation of their idiosyncratic world. ${ }^{1-2}$

Hence, the lifeworld, which on the one hand consists of the same structures, is always related to a particular community of life, structured in different forms, and maintaining a capital distinction between what is seen as "ours", as "own", and other cultural forms as "strange" or "extraneous". ${ }^{2}$

Departing from this reflection, labor was considered as an experience in the lifeworld. 
In that perspective, labor is one of the most important experiences in the lifeworld, an act that originates life itself. Labor, as an event of the lifeworld, represents the summit of the emotional, mental, social and existential phenomena for the woman, infant and family. A phenomenon that women and their families have experienced for a long time in their surrounding world, without the intervention of techniques and the presence of people who were not part of their communitarian world.

The technical and scientific reasons inherent in the field of labor and birth ${ }^{3}$ started to occupy the space of the objectification of the facts in the world and, thus, this rationality started to predominate, so that the field of subjectivity was denied in the context of parturition, losing its original characteristic.

The women stopped giving birth with the help of other women and started to be attended at health institutions, with the presence of other subjects, the health professionals. These, with the support of scientific techniques, transformed the values and practices used at birth, in a technicalized and routine form of the labor process. Thus, the woman giving birth lost the possibility to decide in the labor context, her family is not present in this space and the intersubjective relationships were affected. . $^{4-5}$

In other words, the scientific evolution significantly influenced the life habits and modes of the human beings, covering the lifeworld with a technical-instrumental layer, established by the systematic construction of a world of technological artifacts that induced not only a new form of intersubjective action, but also a new technical-scientific meaning for the world experience.

Giving birth and being born, which are historically considered natural, private, intimate and female, as from the institutionalization of labor in the 1940's, start to be characterized as a specialized technical event in the framework of the health sciences. Consequently, the birth phenomenon tends to be reduced to its strictly biological dimension, with an increasing number of technical care devices. On the other hand, its whole experience and cultural dimension is neglected.

In that context, the purely biological and technocratic view is a founding element of the dehumanization in the field of labor and birth, especially due to the absence of the bond, perpetuating care that is "cold and indifferent, distant from the labor care they ideally wanted to receive" ${ }^{\text {6:225 }}$

Consequently, the woman is no longer the protagonist of the event. The act of giving birth that ceases to exist is the one that represents a unique experience for each woman.

\section{Retreating to the origins of the technicalization of labor care}

The reflection we are now entering on the reduction of birth to a clinical process, centered on its strictly biological dimension, was inspired by paragraph 9 of the book The Crisis of European Sciences and Transcendental Phenomenology: an introduction to phenomenological philosophy, by Husserl".$^{1-2}$ In that paragraph, this work discusses Galileo's mathematization of nature and the technicalization of our relationship with the world built around it. Reflecting about it means meeting this author's initial inquiry: what is the sense of this mathematization of nature and how can we rebuild the course of thinking that motivates it? $5: 37$

Thus, Husserl intends to question what is present today: the practice of science as an organized methodical procedure that does not look at the pre-scientific that induces the lifeworld, wherefrom the scientific activity draws its condition of being possible and its final objective of going to the "true things", moving beyond the relativity and subjectivity of the experience that originated the world. Hence, in line with this reflexive sense of a phenomenological genealogy of scientific activity itself, our ambition would be to perceive the institutions of meaning that guide the construction process of scientific thinking that involves a science of health care, whose fundamental essence should be sought in the life world.

Husserl's $\mathrm{s}^{2}$ thesis about a crisis of the European sciences arouses reflections here about a corresponding crisis in the health sciences, especially the science of labor and birth. The lifeworld, as the original core of meaning, as fundamental evidence, needs to be expressed in its meaningful dimension in order to understand the concepts and theorems of labor and birth care practice, expressing the original stratum the scientific knowledge about labor emerges from, with a view to identifying the meaning that, since the pre-scientific and pre-technical world, conditions and involves the whole technical-scientific apparatus surrounding labor and birth. The return to the lifeworld permits looking at the original cores of meaning and, based on these cores, to inquire on what is supposed to be unquestionable evidence for scientific thinking and practice.

The first evidence in technical-scientific action is that labor and birth are physiological and bio- 
logical events, which should be framed in hospitals concerning that aspect. ${ }^{7}$

The second evidence is that the experience aspects are simply psychological and, as such, merely subjective, without relevance for the labor and birth process (except when they interfere negatively in this process). ${ }^{8}$

The third evidence is that the clinical device, being set up and structured to deal with the biological base of birth and labor, and is therefore free to use non-natural means to precipitate the labor or produce birth (c-section). ${ }^{9}$

As opposed to this evidence, it is observed that:

$1^{\circ}$ - Labor is a human event, which involves and intensifies the fundamental dimensions of subjective, social and communitarian life;

$2^{\circ}$ - Labor and birth have a biological base but are not biological phenomena: they are events of the human world and should be approached as such.

$3^{\circ}$ - As human phenomena, labor and birth are extraordinary events, to the likes of death: if the latter marks the end of a life and the closure of the future, the former, instead, are the opening of the future and the continuation of a social and communitarian lifeworld.

$4^{\circ}$ - Labor care rises in a context of the presence at birth of an entire life community (father, siblings, relatives), in an environment of joyful expectation, and the biological aspects of giving birth, traditionally associated with the presence of a "midwife", are lesser and merely lateral dimensions of the human, social and communitarian phenomena.

$5^{\circ}$ - Labor in the hospital and clinical environment hypertrophied the dimension of the helper and technicalized it, to the extent of excluding any other, thus confining it to its least essential element.

$6^{\circ}$ - Labor care rests on common life and mutual assistance, whose meaningful base is the subjects' common belonging to a community.

Hence, the scientific-naturalist approach of the intersubjective and communitarian phenomena not only does not recognize the subjective experiences of daily life in their origins, but also denies them, as the base to construct the knowledge. Nevertheless, this surrounding lifeworld (Umwelt), which is one of the aspects of the lifeworld (Lebenswelt), experienced in our daily life, is clear to each of us as a pre-scientific, subjective world, with apparitions that truly represent the primordial form of experience of a world for each of us. ${ }^{1-2}$
It is by returning to this pre-scientific world of life and its formations of meaning that the eidosworld can be clarified in its most original structure. In that sense, in practice, the subjective appearance permits empirical foundations that encourage scientific knowledge. According to Husserl [our translation], ${ }^{2}$ "once the search for a 'philosophical' knowledge is aroused that determines the objective 'true' being of the world, the art of empirical mediation, with its objectifying empirical-practical function, was idealized and then turned into the procedure of thinking". 2:24

Science, guided by a scientific practice that intends to investigate the things of the world, guided by the materiality and causality, without considering the lifeworld as a value by itself, only recognizes thinking in the form of objectifying, mathematizing reasons, and comprises all practice, including care, as a specialized technical-scientific procedure. By denying the world apprehended by experience, it ends up concentrating exclusively on a research object constituted as a simply physical and biological entity, without considering its subjective and intersubjective, social and cultural dimensions.

Considering the health and nursing sciences based on the contributions of Phenomenology is a true need, with a view to broadening the perspective beyond the health techniques and understanding the concepts and theorems of health. This urgent process has been a source of nursing reflections. ${ }^{10}$ In that perspective, the capacity of humans to reflect on new events will be acknowledged, granting meaning to the experience lived and mediated by the world, so as to decide on the situations they experience.

The narrow and unilateral scientification, which enables and authorizes the labor and birth care techniques, ${ }^{11-12}$ is based on the excessive use of specialized technologies in the field of pathological reason. In that field, the fact is considered and studied in the light of physiology, perched on sovereign science, and the values and cores of meaning of women's birth experience are considered mere epiphenomena. Thus, science naturalizes the subjective in the field of research by reducing, quantifying and not recognizing the subjectivity as a research field in labor and birth.

Attention is needed to this reduced perspective in the field of the objectification of things, in this case the practice of labor and birth care, because know-how is not only constituted in the objective field; it applies to the subjectivity of the act of giving birth that involves actors in this context of the life- 
world, which has been dismantled by the scientificnaturalistic technicalization of giving birth.

In short, the form of acting and thinking in the sciences of labor and birth care practice denies the subjectivity as the origin for the constitution of meaning, building concepts that operate the world of objectivity, which are not in line with the lifeworld of women in the birth process. Husserl defines it as objectivism of the sciences and reaffirms that it results in "a technicalization of all methods characteristic of the natural sciences [which] are mechanized as a result" 2:63

Thus, "going to the actual things", attempting to see the essence of the scientific process sustaining the practice, means questioning the original sense of labor and birth care. Today, this practice is understood as a dehumanized and mechanized view, acritically adopted in the academy, and the professionals incorporate it while still in training, as one of the most traditional textbooks ${ }^{13}$ in obstetrics uses the metaphor "engine-object-route" to explain the mechanisms of labor: the uterus would be the engine, the fetus the object and the vaginal channel the route. ${ }^{14}$

The sciences underlying the health technologies should guarantee the appropriate quality of this care, with positive results for individuals and groups. In that sense, in labor and birth, the best results and the satisfaction of these service users are expected; for health, it results in the decrease of maternal and perinatal problems. Current studies ${ }^{15-17}$ developed in Brazil reveal the increased number of obstetric interventions, which directly affect the growth in maternal and neonatal morbidity and mortality figures.

Thinking in Husserl's Phenomenology and its interfaces with current times reveals that we are experiencing the need to "clarify the meaning of the origin of the modern natural science [...] dislocation of meaning [...] in a kind of circle [...] the start can only be fully understood based on the sciences in their contemporary form, in a retrospective perspective on their development" ${ }^{\prime 2: 73}$ Hence, the crisis Husserl highlights should call attention to a critical and reflexive analysis, because it is in the fields of life, philosophy, science and human ethics.

Husser ${ }^{2}$ underlines that reason should not be denied, but that one should look at the sciences, in this case labor and birth, based on the lifeworld, of the sensitive experiences and subjectivity, which are original meanings that founded the modern sciences, and therefore meanings that permit a critical and human reflection in health.

\section{FINAL CONSIDERATIONS}

Thinking the health and nursing sciences based on the contributions of Phenomenology is therefore a true need, with a view to expanding the look beyond the health techniques and understanding the intersubjectivity. The application in practice means rescuing the human dignity, taking into account the personal and collective life project, validated in the lifeworld of person in the care situation. That is an urgent process.

\section{Acknowledgments}

The authors thank the Fundação Carlos Chagas Filho de Amparo à Pesquisa do Estado do Rio de Janeiro (FAPERJ)

\section{REFERENCES}

1. Alves PM. Introdução à tradução portuguesa. In: Husserl E. A crise da humanidade européia e a filosofia. Lisboa (PT): Centro de Filosofia das Ciências da Universidade de Lisboa; 2006.

2. Husserl E. A crise das ciências europeias e a fenomenologia transcendental: uma introdução à filosofia fenomenológica. Lisboa (PT): Phainomenon e Centro de Filosofia da Universidade de Lisboa; 2008.

3. Leal MC, Pereira APE, Domingues RMSM, Theme Filha MM, Dias MAB, Nakamura-Pereira M, et al. Intervenções obstétricas durante o trabalho de parto e parto em mulheres brasileiras de risco habitual. Cad Saúde Pública [internet]. 2014 [cited 2015 mar 22]; 30(Suppl):S17-47. Available from: http:/ / www.scielo.br/scielo.php?pid=S0102311X2014001300005\&script=sci_arttext

4. Victora CG, Aquino EML, Leal MC, Monteiro CA, Barros FC, Szwarcwald CL. Maternal and child health in Brazil: progress and challenges. The Lancet, 2011; 377(9780):1863-1876.

5. Frello AT, Carraro TE. Componentes do cuidado de enfermagem no processo de parto. Rev Eletr Enf [internet]. 2010 [cited 2015 mar 22]; 12(4). Available from: http://www.fen.ufg.br/revista/v12/n4/ v12n4a10.htm

6. Santos LM, Pereira LMSSC, Santos VEP, Santana RCB, Melo MCP. Relacionamento entre profissionais de saúde e parturientes: um estudo com desenhos. Rev Enferm UFSM [internet]. 2011 [cited 2015 out 02]; 1(2). Available from: http://cascavel.ufsm.br/revistas/ ojs-2.2.2/index.php/reufsm/article/view/2588/1635

7. Dias VF, Schneck CA, Riesco MLG. Intervenções obstétricas no trabalho de parto em mulheres submetidas à cesariana. Cogitare Enferm [internet]. 2007 [cited 2015 out 01]; 12(3). Available from: http:/ / ojs.c3sl.ufpr.br/ojs/index.php/cogitare/article/ viewFile/10023/6884 
8. Mazzoni A, Althabe F, Liu NH, Bonotti AM, Gibbons L, Sánchez AJ, Belizán JM. Women's preference forcaesarean section: a systematic review and metaanalysis of observational studies. BJOG [internet]. 2011 [cited 2015 Oct 05]; 118(4). Available from: http://www.ncbi.nlm.nih.gov/pubmed/21134103

9. Castro LMR, Riesco MLG, Schneck CA, Angelo M. Reflexões sobre o excesso de cesarianas no Brasil e a autonomia das mulheres. Ciênc Saúde Coletiva [internet]. 2013. [cited 2015 out 01]; 18(8). Available from: http:/ / www.scielo.br/scielo.php?pid=S1413$81232013000800024 \&$ script $=$ sci_arttext

10. Guevara B, Evies A, Rengifo J, Salas B, Manrique D, Palacio C. El cuidado de enfermería: una visión integradora en tiempos de crisis. Enferm Glob [internet]. 2014 [cited 2015 mar 22]; 13(33). Available from: http://scielo.isciii.es/pdf/eg/v13n33/ensayo2.pdf

11. Malheiros PA, Alves VH, Rangel TSA, Angel TSA, Vargens OMC. Labor and birth: knowledge and humanized practices. Texto Contexto Enferm [internet]. 2012 [cited 2015 mar 22]; 21(2). Available from: http://www.scielo.br/scielo.php?pid=S010407072012000200010\&script=sci_arttext

12. Prata JA, Progianti JM, David HSL. Productive restructuring in the area of health and obstetric nursing. Texto Contexto Enferm. [Internet]. 2014 [cited 2015 Oct 05]; 23(4). Available from: http://www. scielo.br $/$ scielo.php?script $=$ sci_arttext\&pid $=$ S010407072014000401123\&lng=en\&nrm=iso\&tlng=en

13. Rezende J. Obstetrícia. 6.ed. Rio de Janeiro (RJ): Guanabara Koogan; 1992.

14. Rattner D. Humanização na atenção a nascimentos e partos: breve referencial teórico. Interface (Botucatu) [internet], 2009 [cited 2015 mar 22];13(suppl.1). Available from: http://www.scielo.br/scielo.php?script=sci_ arttext\&pid=S1414-32832009000500011

15. Leal MC, Silva AAM, Dias MAB, Gama SGN, Rattner D, Moreira ME, et al. Birth in Brazil: national survey into labour and birth. Reproductive Health. 2012; 9:15

16. Santos IS, Matijasevich A, Silveira MF, Sclowitz IK, Barros AJ, Victora CG, et al. Associated factors and consequences of late preterm birth: results from the 2004 Pelotas birth cohort. Pediat Perinat Epidemiol, 2008; 22(4):350-9.

17. Aquino EML. Para reinventar o parto e o nascimento no Brasil: de volta ao futuro. Cad Saúde Pública [internet]. 2014 [cited 2014 Set 11]; 30(Suppl 1):S8-10. Available from: http:// www.scielo.br/scielo.php? script=sci_ arttext\&pid=S0102311X2014001300002\&lng=pt
Correspondence: Valdecyr Herdy Alves

Universidade Federal Fluminense

Centro de Ciências Médicas - Escola de Enfermagem

Rua Dr. Celestino, 74

24.020-091 - Centro, Niterói, RJ, Brasil

E-mail: herdyalves@yahoo.com.br
Received: May 14, 2015

Approved: November 13, 2015 